\title{
Again, making Tanzania great: Magufuli's restorationist developmental nationalism
}

\author{
Dr. Dan Paget \\ Department of Political Science, University College London, London, United Kingdom \\ 29-31 Tavistock Square, London, WC1H 9QU. \\ Email: ‥paget@ucl.ac.uk | Twitter: @pandaget \\ Website: danpaget.com | ORCID ID: https://orcid.org/0000-0002-3883-1649
}

This paper was accepted for publication by Democratization in May 2020. This is the version of the paper submitted to the journal, before in-house proof-reading and formatting. 


\section{Again, making Tanzania great: Magufuli's restorationist developmental nationalism}

This article is about how ideologies legitimize authoritarianism. The literature argues that liberation nationalists discursively construct "liberation" as an ongoing struggle and justify their authoritarian rule until its completion. By recurrently postponing liberation, they extend this justification of authoritarianism. Nonetheless, their claim that the nation is part-way through liberation becomes less plausible over time. Liberation nationalism shares a discursive structure with a parallel class of developmental nationalisms. I analyze the ideology of President Magufuli and CCM in Tanzania. Instead of claiming that the nation is mid-transformation, they constructed the status quo as a corrupt deviation from a past order: "Nyerere's Tanzania". They conceived of this past order as a nation dedicated to industrial development which would lead to a transformed future. They advocated rupture with the present, the restoration of the past and the resumption of this transformative journey. Restorationism relieves liberation and developmental nationalisms of the rising rhetorical challenge of claiming that the nation has been on a transformative path since liberation. Therefore, Magufuli and CCM developed a variant upon liberation and developmental nationalisms, which also justifies authoritarianism. Unlike them, it remains rhetorically viable as the moment of liberation or development becomes distant. I call it restorationist developmental nationalism.

Keywords: authoritarianism; liberation; development; nationalism; restorationism; populism; Tanzania; Africa; ideology; discourse-theoretic.

Word count: 9,000 
Liberation nationalists in power employ a common rhetorical device. First, they portray "liberation" as ongoing rather than achieved. ${ }^{1}$ Second, they justify their authoritarian rule while it continues. ${ }^{2}$ Third, they recurrently raise the pass-bar for "liberation" and so postpone its completion. ${ }^{3}$ Alex Beresford writes that this makes liberation nationalisms potentially "regenerative"; ${ }^{4}$ they can repeatedly extend their justifications of authoritarianism or electoral authoritarianism. However, this regeneration has limits. ${ }^{5}$ As time passes, it becomes ever-less plausible that the nation is still mid-transformation and has been since liberation. Thereby, the viability of this ideology to legitimize authoritarianism wanes. Liberation nationalism shares a discursive structure with a parallel class of developmental nationalisms which conceive of processes of development rather than liberation. ${ }^{6}$

In Tanzania, President John Pombe Magufuli was elected in 2015. He and his party, Chama cha Mapinduzi (CCM) or "the Party of the Revolution", developed a creative variant on liberation and developmental nationalisms. They instrumentalized this ideology to justify a sharp authoritarian turn which began in $2014 .{ }^{7} \mathrm{I}$ analyze the discourse they crafted. I adopt the discourse-theoretic perspective of Ernesto Laclau and Chantal Mouffe and treat ideologies as discourses underpinned by logics of articulation. ${ }^{8}$ Analyzed through this lens, CCM's reconfigured ideology is united with liberation and developmental nationalisms by similarities, but separated from them by differences, which turn on the destinations they envisage. Like liberation and developmental nationalisms, CCM ultimately imagined a possible future, as yet never realized, in which the nation is transformed. However, it also imagined a past order, namely "Nyerere's Tanzania", which was not static, but in motion, a nation organized for and dedicated to development. It constructed the present as a corrupt deviation from 
that old order. CCM advocated the restoration of that past, and thereby, the resumption of the developmental path towards the transformed future. Therefore, this discourse is simultaneously radical, reactionary and progressive. This backward-looking aspect distinguishes it from other liberation and developmental nationalisms. I name it restorationist developmental nationalism.

This restorationism makes that variant of liberation and developmental nationalist ideologies a possibility, and indeed, a reality, beyond its conventional settings. Conventionally, these ideologies are only rhetorically compelling under a small and narrowing range of circumstances, but restorationist developmental nationalism is rhetorically versatile; it could be employed to justify authoritarianism across much of sub-Saharan Africa, and beyond. This is particularly relevant given the contemporary African and global authoritarian turn. ${ }^{9}$ For clarity, I do not claim that this ideology has "caused" authoritarian regime survival or re-autocratization in Tanzania, which is better explained by $\mathrm{CCM}$ patronage and institutionalization, ${ }^{10}$ state-party merging, ${ }^{11}$ social engineering, ${ }^{12}$ and the rise of the opposition. ${ }^{13}$ Discourses give the social world form and meaning; ${ }^{14}$ I argue that through this discourse, people understand CCM's authoritarian rule as legitimate, ${ }^{15}$ it justifies authoritarianism.

Finally, I contribute to the characterization of Magufuli's political project, principally from 2015 to 2018. Past studies of Magufuli's project adopt realist-objectivist perspectives $;{ }^{16}$ they presuppose that there is an objective social world ${ }^{17}$ and focus on Magufuli's "material” policies. ${ }^{18}$ I complement these realist-objectivist characterizations of Magufuli project by interpreting and distilling the ideology through which Magufuli and CCM subjectively describe it. ${ }^{19}$ While past studies of Magufuli 
"material" politics identify continuities with the status quo, I argue that they discursively construct a rupture with it.

Researching discourse raises methodological challenges about interpreting meaning in context, inferring implicit meaning, distilling coherence from contradictory statements, and selecting sources. ${ }^{20}$ I faced an additional challenge; I am not fluent in Swahili. To address these challenges, I studied a wide range of sources. ${ }^{21}$ I collected the transcripts of politicians' speeches. I drew on a personal archive of more than 2,000 newspaper articles selected for relevance, most published between 2013 and 2019. I examined a grey literature of official documents. I examined opinions expressed by Tanzanians on Twitter, as a participant. This built on extensive field work and 151 interviews I conducted for previous research. I relied on three practices to become conscious of and respond to any prejudices arising from my subjective perspective and source selection. First, I reflected on my positionality and perspective. ${ }^{22}$ Second, I commissioned Tanzanian research assistants to look for further sources which I may have missed, with a clear brief designed to minimize bias. For transparency, I mark sources found and translated by them with an asterix. All other quotes are reported in the language in which they are presented in the sources. Third, I repeatedly conferred with Tanzanian analysts of Tanzanian politics, and in particular one academic, four journalists and columnists, and one opposition politician. ${ }^{23}$ I recognize these peers in the acknowledgements and attribute points which I owe to their insights in the text.

In the next section, I conceptualize liberation and developmental nationalisms through a discourse-theoretic perspective. I compare them to restorationist developmental nationalism, which I develop theoretically in the second section. In the third section, I 
locate my study in the Tanzanianist literature. In the remaining sections, I detail the restorationist developmental nationalism expressed by Magufuli and CCM.

I wish to clarify three points before proceeding. First, on periodization, many of the changes in CCM's discourse which I describe began in $2011,{ }^{24}$ when CCM began what it described as "rebranding" after losing ground in the 2010 election. ${ }^{25}$ However, they achieved full expression from 2015 to 2018 during Magufuli’s presidency. Second, on attribution, CCM and Magufuli often expressed their discourse in unison. Where they do, I refer to them interchangeably; to attribute the discourse to Magufuli's alone would mischaracterize a collective project as an individual one. However, Magufuli took a leading role in expressing several aspects of their discourse, including constructing and performatively fighting corruption, which I note in the text. For brevity, I do not cover the 2019 dissent by marginalized CCM politicians. Third, liberation and developmental nationalisms in and out of power may differ. My discussion focuses on them in power.

\section{Liberation and developmental nationalisms}

African liberation nationalisms differ in principle. The first generation subscribed to socialism and won "liberation" in the 1950s and 1960s. The second generation either never adopted or subsequently eschewed socialism and won "liberation" violently between the 1970s and 1990s, notably in South Africa, Zimbabwe, Rwanda, Angola, Namibia, and Eritrea. ${ }^{26}$ The socialists differed in principle too. They were divided between an early wave of self-proclaimed "African socialists" and a later wave of "Afro-Marxists". ${ }^{27}$ Both sub-strains differed in turn; as Joy Hendrickson and Hoda Zaki write, there were "many varieties of African socialism". ${ }^{28}$ Likewise, Crawford Young judged that "the new wave of Afro-Marxist regimes is not homogeneous in ideological 
interpretation or policy practice." 29 Therefore, it is unclear what tenets unite liberation nationalisms.

However, liberation nationalisms share a discursive structure. Beresford argues that post-Apartheid, South Africa's African National Congress (ANC) presents liberation as “an ongoing (and seemingly infinite) 'National Democratic Revolution'... which it alone is mandated to fulfil." ${ }^{30}$ Blessings-Miles Tendi and Sara Dorman argue that the Zimbabwe Africa National Union-Patriotic Front (ZANU-PF) imagines a similar ongoing liberation and claims unrivalled authority to fulfil a equivalent liberation mandate. ${ }^{31}$ Dorman and others argues that "post-liberation" regimes imagine national struggles against foreign enemies, ${ }^{32}$ especially ZANU-PF. ${ }^{33}$ Both liberation and national struggle underpin exclusionary politics ${ }^{34}$ opposition is characterized as seditious either because it militates against liberation, or because it is serves foreign enemies, or both. ${ }^{35}$ Exclusionary politics also encompasses the delegitimation of "divisive" ethnic politics. ${ }^{36}$ In these pages, Beresford, Marie Berry and Laura Mann offer perhaps the clearest synthesis of these studies. ${ }^{37}$ They argue that liberation movements construct liberation as an incomplete but ongoing transformation. This "liminality" or betweenness of liberation generates "extraordinary mandates" for liberation parties which justifies "authoritarian social contracts" and "political abjection" of their opponents. ${ }^{38}$ I build on these insights by drawing on the discourse-theoretic perspective propounded by Laclau and Mouffe and further developed by Jason Glynos and David Howarth, perhaps best known for its conception of populism. ${ }^{39}$ A discourse, thus defined, constructs how the world is and ought to be through logics of articulation. "Logics of equivalence" and "difference" construct identities and relate them antagonistically, 
Democratization

respectively. World-views are partial and fix meaning through sets of "signifiers". In particular, they construct social orders from which a society or nation departs or upon which it converges. They function through "fantasmic logics"; 40 their contents are partially specified and partially unspecified. ${ }^{41}$ These ambiguities leave room for people to invest destinations constructed as desirable and undesirable with their hopes and fears or the "beatific" and "horrific" respectively. ${ }^{42}$ Therefore, the partial specification of these social orders is potentially instrumental.

Following Glynos and Howarth, and Benjamin de Cleen, a nationalist discourse interpellates a subject as "the nation" and constructs an antagonism between it and "the foreigner" ${ }^{43}$ Interpreting the liberation nationalist literature through the discoursetheoretic perspective, a liberation discourse interpellates people as members of a society being liberated. It constructs "liberation" as a transformed future through logics of fantasy and portrays reaching it as imperative. It portrays the regime as the sole legitimate steward of liberation, and invokes that future to deny, depoliticize and postpone people's demands against it. ${ }^{44}$ A liberation nationalism articulates the two. It interpellates a subject as "the nation" being liberated and constructs "liberation" as a destination that "the nation" will reach. It denies, postpones and depoliticizes peoples' demands in anticipation of that future. Thereby, it justifies authoritarian measures. Finally, it generates an antagonism between "the nation" and their foreign opponents that militate against national liberation. It characterizes domestic opposition as foreign agents and thereby justifies further authoritarian measures against them.

Liberation nationalism has a developmental twin. James Ferguson, among others, argues that developmental discourses imagine futures and deny or delegitimize popular 
demands, like liberation nationalisms. ${ }^{45}$ Development and nationalist discourses have long been combined, just as liberation and nationalist discourse have been. Radika Desai conceptualizes "developmental nationalism", ${ }^{46}$ which is the subject of a special issue of Third World Quarterly. Studied through a discourse-theoretic perspective, developmental and liberation nationalisms share a logic of articulation. Exchanging "development" for "liberation", they make equivalent claims. This analysis is derivative of prior analyzes; its expression in discourse-theoretic terms is intended to be clarificatory.

This logic of articulation is common to African liberation and developmental nationalisms. Julius Nyerere's Ujamaa na Kujitegemea, or "socialism and self-reliance" is a prime example. ${ }^{47} \mathrm{He}$ construed liberation as an ongoing endeavour to achieve socialism. ${ }^{48} \mathrm{He}$ constructed antagonisms with exploitative foreigners. ${ }^{49}$ He rendered criticism and ethnic politics alike as unpatriotic and opposition as seditious by placing them in opposition to this socialist mission. ${ }^{50}$ Similarly, Kwame Nkrumah propounded an "African revolution" in-progress against both "indigenous exploiting classes and neocolonialists" which would yield a "fundamental transformation of society." discourse-theoretic expression captures an essence behind the "state moving towards the future" which Dorman ascribes to many African nationalisms, and the "brighter national futures" which Desai ascribes to developmental nationalisms. ${ }^{52}$

Liberation and developmental nationalisms are not and need not be alike in all other respects. Anti-political nationalist discourses construct the nation as united and construct ethnic and separatist movements as divisive threats. ${ }^{53}$ Separatist nationalisms imagine peoples denied sovereign statehood by foreign oppressors. ${ }^{54}$ Nativist 
Democratization

nationalisms vilify foreign allochthons which threaten national autochthons. ${ }^{55}$ Each such nationalist discourse corresponds to a distinct logic of articulation which could be expressed alone or combined with liberation and developmental nationalist logics of articulation. ${ }^{56}$

The rhetorical durability of liberation nationalist discourses - and by extension, developmental nationalist discourses - is contested. Earlier accounts speculated that demographic change, fading memory of liberation and business capture would give liberation nationalist regimes what Dorman calls "expiry dates", ${ }^{57}$ limitations which Beresford recognized. ${ }^{58}$ Later accounts claim that their ability to recurrently redefine, and therefore repeatedly delay liberation makes these discourses what Beresford calls "potentially regenerative". ${ }^{59}$ Similarly, Beresford, Berry and Mann argue "liberationideology is not a time-bound, finite political resource of... 'heroic' liberation movements. ${ }^{60}$ Nonetheless, as the past moment of liberation becomes more distant, and nations' paths digress further from those imagined, it becomes prima facie gradually less plausible to claim that the nation is mid-liberation and has been all this time. Regimes must recurrently surpass this rising rhetorical bar to sustain these discursive claims and therefore maintain the legitimacy of their authoritarian rule. While they may succeed in doing so, it will be in spite of this growing void between "the real" and the discursive. It is perhaps illustrative that the only remaining regimes which express liberation nationalisms were borne of a late wave of violent struggles. ${ }^{61}$

\section{Back to the future}

I conceptually develop restorationist developmental nationalism as a variant on liberation and developmental nationalist discourses. The distinctiveness of this variant turns on the destinations in time which it envisages. While many ideologies construct 
future destinations as yet unrealized, not all do. Following de Cleen, ideologies articulated through a "conservative political logic" interpellate people as members of an idealized present social order which is under threat. ${ }^{62}$ Similarly, ideologies articulated through a "reactionary political logic" advocate a rupture with the present social order in order to reinstate an idealized past order. ${ }^{63}$ As de Cleen defines them, these mark the discursive boundaries of a spectrum of right-wing ideologies. Copious instance of "authoritarian nationalisms" from twentieth-century Europe analyzed by Stanley Payne exemplify these treatments of the present and past. ${ }^{64}$

Restorationist developmental nationalism imagines destinations in both the past and the future. It constructs a future transformed, as yet unrealized, in utopian terms. It imagines a prior order in which national policy was set in pursuit of one goal: the achievement of that future. Therefore, this old order represents a trajectory, rather than a final destination. This discourse characterizes the status quo as a deviation from that prior order. It advocates a rupture with the present to restore the past. Thereby, it proposes the resumption of the transformative journey to the future.

This discourse generates two sets of antagonism. On one level, it interpellates "the people" as "the nation" and sets them against foreign enemies and their domestic agents who militate against the nation's development. On another, it interpellates "the people" as "the plebs" and pits them against illicit beneficiaries of the current (deviated) order. This second, vertical dimension of conflict means that restorationist developmental nationalism is simultaneously populist, or to borrow a recently-developed sisterconcept, elitist plebeian. ${ }^{65}$ Defined briefly, populist discourses bifurcate the social between "the elite" and "the people", and vilify the former; elitist plebeian discourses 
trifurcate the social between "the (virtuous) elite", "the people", and a middle stratum, and vilify the latter. ${ }^{66}$ De Cleen theoretically develops how populist and nationalist discourses can be combined ${ }^{67}$ In restorationist developmental nationalisms, a populist (or elitist plebeian) discourse is subsumed within a nationalist one; "the people" as plebs struggle against an enemy above so that they can resume a developmental journey and recommence a grander struggle of "the people" as "the nation" against foreigners. See Margaret Canovan on these two meanings of "the people". ${ }^{68}$

Relatedly, in this discourse, authoritarian measures are not justified through a populist logic as the overthrow of "the elite" and the destruction of liberal institutions which deny the "people's will". ${ }^{69}$ By this logic, breaking liberal institutions realizes the ascent and representation of the "the people". ${ }^{70}$ Instead, it justifies authoritarianism through a liberation or developmental nationalist logic as an extraordinary measure which is necessary in the context of a vital national struggle and in the pursuit of imperative national transformation. The former justifies authoritarianism as the realization of true democracy. The latter justifies the suspension of democracy.

Restorationist developmental nationalism differs from liberation and developmental nationalisms, which envisage "forward progression" to transformed futures. ${ }^{71}$ While some such discourses imagined futures which incorporated idealized elements of the past, such as Nyererean African democracy, Nkrumahist communalism, or Touréan communicratique societe, the societies that they set out to create were nonetheless new, societies as yet unrealized. Machel's "new man"72 and Nkrumah's "new society"73 are among the most vivid examples of such forward-looking utopianisms. Restorationist developmental nationalisms share this ultimate goal of realizing a transformed future. 
However, like reactionary ideologies they pursue the return to an idealized past, ${ }^{74}$ albeit as only an intermediary junction.

Restorationist developmental nationalisms bears several rhetorical advantages. First, it generates antagonisms on several fronts. Second, it carries the radical allure of a rupture with the present, the nostalgic anticipation of the past, and the optimistic anticipation of the future. Third, it is rhetorically versatile. It relaxes the language of liberation and circumvents the high rhetorical bar of claiming that the nation has continuously been on a transformative path since liberation. Instead it need only be claimed that once the nation followed a transformation path, to which it should return. Therefore, restorationism makes the application of this discourse flexible.

\section{Studying political discourse in Tanzania}

In this paper, I build on studies of Magufuli's project by Thabit Jacob and Rasmus Pedersen, Japhace Poncian, and Sabatho Nyamsenda. ${ }^{75}$ They describe how Magufuli articulates an anti-foreign nationalism; claims to defend the poor; likens himself to Nyerere; portrays opposition to it as unpatriotic; and claims the authority to verify truth. However, they adopt realistic-objectivist perspectives. ${ }^{76}$ They presuppose that there is an objective social world. Accordingly, they study Magufuli's rhetoric in relation to his "policy measures"77 or "policy interventions". ${ }^{78}$ For example, Jacob and Pedersen argue that "Magufuli's interventions... mark not a break, but a continuation of the resource nationalism that began under [former president] Kikwete."79 They argue that changes in these policies" "appearance" and "style" masked these continuities. ${ }^{80}$ They clarify their ontological presuppositions in a later working paper, in which they suppose that discourse and material policies necessarily converge "in the long run". ${ }^{81}$ By contrast, I 
presuppose that the social world is subjective. Instead of analyzing the policies which underpin Magufuli's project, I interpret how he and CCM characterize it themselves.

CCM revised its rhetoric within a particular discursive context. After structural adjustment, CCM had "reconfigured" its discourse. ${ }^{82}$ It had selectively rejected the ideology of Ujamaa. It had shorn socialist and liberation terms from its vocabulary. ${ }^{83}$ It elevated paternity as seniority, providership and (ethnically-harmonious) peace ${ }^{84}$ in its rhetoric. ${ }^{85}$ It rehabilitated its image for development from 2011 in particular. ${ }^{86}$ As Felicitas Becker, Marie-Aude Fouéré, and Aikande Kwayu all argue, Nyerere and Ujamaa remained ever-present in political rhetoric. ${ }^{87}$ Most prominently, Fouéré argues that Ujamaa and Nyerere became "sites of memory". ${ }^{88}$ She stresses that actors drew on this shared resource creatively, and in numerous ways. However, she argues that the most prominent such way was as a "reservoir of positive moral principles." ${ }^{\text {" In }}$ other words, people invoked Ujamaa as an abstraction, a "shared political language employed in the present to articulate conceptions of morality, belonging, and citizenship. ${ }^{, 90} \mathrm{I}$ argue that under Magufuli's leadership, CCM drew on Ujamaa and Nyerere in two ways, which Fouéré and others recognize but treat as secondary. CCM treated "Nyerere's Tanzania" not as a moral abstraction, but as a discourse from which it borrows and as a just and purposeful social order which it imagined and promised to reinstate.

In the following three sections, I interpret the restorationist developmental nationalism expressed and used to justify authoritarianism primarily between 2015 and 2018. Space is scarce, so I focus on the most prominent aspects of this discourse. 


\section{"Following Nyerere's footsteps"}

CCM, and Magufuli in particular, criticized corruption in government. They used terms which were partly moral. Magufuli described "the rot that is in this country". ${ }^{91}$ In an extension of this putrid metaphor, he promised to tumbua majipu or "lance the boils". Some have characterized this war on corruption as populist which, accordingly, vilified "the elite", namely CCM. ${ }^{92}$ However, Magufuli did not present CCM as the target of the anticorruption drive. Instead, he characterized bureaucrats and businessmen as the propagators of corruption. Far from vilifying $\mathrm{CCM}$, Magufuli said that " $\mathrm{CCM}$ is here and will continue to be here - forever". ${ }^{93}$ Therefore, CCM's message was not a populist vilification of "the elite", but an "elitist plebeian" heroization of "the elite" and vilification of a middle stratum..$^{94}$

This framing was instrumental for CCM, and Magufuli in particular. Opponents of CCM had purveyed an image of corruption in government. ${ }^{95}$ Magufuli's discourse enabled him to accept the widespread allegations of corruption while exonerating the party of government. He repeatedly sacked state officials, directors, executives and board members. In effect, Magufuli performatively relocated corruption from the party to the bureaucracy. ${ }^{96}$ Further still, Magufuli portrayed his presidency as a cleansing of CCM, separating the party from rogue elements within. Former president Kikwete said that CCM was "cleaning up" by removing "traitors" and "saboteurs". ${ }^{97}$ With each dismissal, implicitly, CCM became cleaner. In 2019, Magufuli appointed a new Controller and Auditor General, Charles Kichere. Kichere's 2020 report sustained this portrayal. It reported corruption, but not at the apex of government, but in agencies, local administration, parastatals, and foreign missions, which central government might arrest. $^{98}$ 
This discourse also equipped Magufuli with a ready-made corruption allegation to deploy in internal party struggles. This not only created a pretext to dismiss them but discredit them. CCM expelled rumoured presidential challenger Bernard Membe for alleged misconduct. Magufuli tacitly suggested that he sacked high-flying cabinet members Mwigulu Nchemba and January Makamba for corruption and underperformance respectively. Similarly, this agenda created a ready-made script to deflect blame from the president and party to individuals. Magufuli sacked cabinet ministers Sospeter Muhongo, Charles Tizeba, Charles Mwijage and Kangi Lugola, among others, as part of performed interventions in scandals and crises.

Magufuli presented his actions as a rupture rather than gradual change. He theatrically fired officials for corruption and laziness on-the-spot. He dismissed 10,000 civil servants for falsifying transcripts. ${ }^{99}$ Magufuli portrayed the present order as potentially ruinous, and concomitantly, the changes which they advocated as literally vital. Magufuli said that "The measures I am taking are aimed at saving this country."100 Therefore, whether or not CCM's policies featured continuities with the status quo, they were presented as a fundamental break with it; policy and discourse differed.

This rupture involved a reinstatement of Nyererean virtues, notably work, thrift and "thinness". These virtues were expressed through the performed elimination of their constructed opposites, namely laziness, largesse, and greed. However, they are also expressed positively. Magufuli's 2015 campaign slogan was “hapa kazi tu”, or “only work here”. Similarly, Magufuli reduced salaries, cabinet-size and government air- 
travel. In these respects, CCM's restoration invoked Nyerere as a "language of morality", consistent with Fouéré and others. ${ }^{101}$

For context, these claims were challenged by opposition and civic voices. At first, they alleged that the new anti-corruption drive focused on petty corruption and spared CCM grandees. ${ }^{102}$ Later, they alleged that Magufuli's appointments were nepotistic. ${ }^{103}$

CCM also wove a reinstatement of morals, portrayed as "traditional", into this restorationism. It took theatrical action against after-hours drinking, shisha-smoking, underage pregnancy, birth-control, LGBTQ people ${ }^{\mathrm{i}}$ and drugs. ${ }^{104}$ These issues were not prominent aspects of Ujamaa, but they gained definition in contrast to a constructed liberal morality supposedly imposed by foreigners. For example, it was alleged that INGOs promoted homosexuality. ${ }^{105}$ By defending LGBTQ rights and female reproductive rights, donors and INGOs reinforced these associations. ${ }^{106}$

However, the centre-piece of this self-portrayed restoration was the revival of a project of national transformation. ${ }^{107}$ Industrialization received pride of place in CCM's National Five Year Development Plan 2016/17-2020/21. ${ }^{108}$ This restorationist project integrated many CCM policies. Instead of focusing on these policies' content, I focus on how CCM discursively presented them as a return to Nyerere's Tanzania. At the inauguration of the $11^{\text {th }}$ Parliament, Magufuli declared that "there is no other way but industrialization." 109 Ujamaa concentrated primarily on rural development rather than urban. Nonetheless, industrialization was characterized as Nyerere's project. For

\footnotetext{
i Typically they refer to "gays" or "homosexuality".
} 
example, one deputy minister said that the government's actions "showed the effort to implement Mwalimu Nyerere's agenda of the industrial economy."110

This elevation of industrialization was accompanied by an extension of state economic intervention. The Five Year Plan is replete with such proposals. ${ }^{111} \mathrm{CCM}$ presented privatization as part of the drift of the status quo. Magufuli said that "we privatized even strategic industries like the railways corporation. It's like we decided to leave each and everything to investors, which was wrong." 112 Likewise, CCM portrayed the reassertion of the state as a return to the past. ${ }^{113}$ This had a basis in historical record, but CCM belaboured the parallels. Altogether, it selectively remembered aspects of the past by lamenting abandoned policies and celebrating policies to be revived.

CCM promoted several projects as emblems of this so-called resumption of Nyerere's project. First, CCM restarted the transfer of government to Dodoma. ${ }^{114}$ Nyerere and his party had designated Dodoma as the capital and resolved to relocate government ministries there, but had only partially done so. Magufuli said:

the Father of the Nation [Nyerere], in 1973, said let us move to Dodoma... We are moving to Dodoma and I am about to finish-up [transferring my office there]. ${ }^{115}$

Therefore, he expressed his intention to literally complete a project which Nyerere had begun. Senior CCM politician Pancras Ndejembi said that by moving to Dodoma, "Magufuli is following Nyerere's footsteps". ${ }^{116}$

Second, Air Tanzania Company Limited (ATCL), bought a Boeing 789 Dreamliner and several smaller airplanes. CCM characterized this as the revival of the national airline, which was founded in 1977 under Nyerere. A government spokesperson said that "The 
787 Dreamliner will be the flagship aircraft as we renew and grow the Air Tanzania fleet [emphasis added]". ${ }^{117}$ Magufuli said that "We have restored ATCL to bring back our national reputation [emphasis added]". ${ }^{118}$ Accordingly, the arrival of the Dreamliner was greeted with pomp and ceremony. ${ }^{119}$ Similarly, CCM revived the long-dormant Stiegler's Gorge hydro-dam project. ${ }^{120}$ Barnaby Dye analyzes its wider ideological significance. ${ }^{121}$ Magufuli described this as a dream conceived of in the 1970s; he promised to fulfil it and, tellingly, re-named it "Nyerere Gorge". ${ }^{122}$ Likewise, CCM commissioned a series of standard-gauge (high-speed) railways, which invited parallels with the Ujamaa-period Tanzania-Zambia TAZARA Railway.

Thereby, CCM constructed these projects and policies as signifiers of the restoration of Nyerere's plan. At a staged meeting with Nyerere's widow, Magufuli said "Everything that the Father of the Nation wished to do, like Stiegler's Gorge, self-reliance, we see its result when we try to do it". ${ }^{123}$ He continued "if you read the Arusha Declaration, you realize...everything that our country was supposed to build is in there". ${ }^{124}$ Therefore, CCM invoked Nyerere not primarily to express moral principles, as Fouéré described others doing in the past, but as a constructed policy agenda, selectively remembered, which it was reinstating. Few objected to the restoration of "Nyerere's Tanzania" in principle. ${ }^{125}$ However, for context, the opposition portrayed its tax initiatives as shorttermist and its plane-buying as improper and imprudent. ${ }^{126}$

"Nyerere's Tanzania”, “Nyerere's plan”, "Nyerere's footsteps" and other synonymous terms became signifiers for a past social order which encompassed this programme. This discourse has been enriched and sometimes complicated by other voices. In 2018, the hashtag \#MATAGA gained prominence Twitter, an acronym for "Make Tanzania 
Great Again" in imitation of Donald Trump. One active advocate of Magufuli, whose true identity remains unknown, ${ }^{127}$ tweeted:

\#MATAGA MAKE TANZANIA GREAT AGAIN! Tanzania was great before the grand corruption destroyed the country. ${ }^{128}$

A more accurate expression of CCM's own discourse would be that it was resuming the task of making Tanzania great; it was, again, making Tanzania great.

\section{"New Tanzania"}

In CCM's revised discourse, industrialization had a purpose and the nation had a destination. Magufuli said "I am steering the country in the right direction. I believe we would reach there and achieve our goal."129 Likewise, "Nyerere Dam" would help "to reach where we are destined". ${ }^{130}$ This national destination was "to be an industrial country". ${ }^{131}$ Therefore, restoration of the past recommenced a journey to the future. However, a new term became especially prominent CCM's vocabulary in 2018 which signified this destination: "Tanzania Mpya" or "New Tanzania."

The contents of this destination were specified in bureaucratic detail. The Five Year Development Plan brims with specific interventions and lists of targets. However, it remained only partially constructed in public-facing rhetoric. CCM repeatedly stated that through industrialization, Tanzania would "produce mass jobs"132 and "elevate the living standards of Tanzanians". ${ }^{133}$ Justice, equality and the end of exploitation were all absent from these goals; therefore, like other re-imaginations of the Ujamaa, ${ }^{134}$ this restoration shore it of socialism, as opposition politician Zitto Kabwe stressed. ${ }^{135}$ 
While these goals might seem mundane, they were construed as metamorphic. CCM privileged projects like Stiegler's Gorge and Air Tanzania which evoke modernity. Both dams and planes involve the conquest of humankind over nature, the first by reshaping landscapes, the second through human flight. ${ }^{136}$ These two items became objects of fantasy. \#MATAGA was coupled to another Twitter hashtag, \#NiSisiSisi, an abbreviation of "Sisi ni Tanzania Mpya", or "We are the New Tanzania". Many users produced and tweeted images of Dreamliner planes carrying this hashtag. ${ }^{137}$ Others tweeted images of gleaming industrial plants. ${ }^{138}$ They illustrate ways in which people imagined "New Tanzania" through and in association with these symbols. CCM encouraged these utopian imaginaries. Magufuli said of the Dreamliner "the developed Tanzania, the respected Tanzania, the prosperous Tanzania is coming."139

The realization of national development was presented as an imperative which transcended other political considerations. In this context, "only work here" took on a different meaning; it represented not only virtue, but dedication to this cause. Magufuli justified the curtailment of officials' amenities by declaring “we must make sacrifices." ${ }^{140}$ Similarly, Magufuli postponed popular demands as he castigated a public rally; "government obligation is to provide... roads and supplying medicine, not relief food for lazy people". ${ }^{141}$.

In sum, CCM constructed the present as a corrupt and deviant status quo and the Ujamaa period as a past order which Tanzania should reinstate. This restoration involved resuming the endeavour to create "New Tanzania". 


\section{"Tanzania first"}

Like other developmental and liberation nationalisms, CCM coupled the imagination of a transformed future with a national struggle against mabeberu or "imperialists". Kikwete's cordial approach to miners had contained moments of hostile rhetoric. However, Magufuli's rhetoric became bellicose and he initiated far-reaching mining reforms in 2017. These reforms followed the direction of travel charted by Kikwete. ${ }^{142}$ However, Magufuli portrayed them not as a continuation of policy, but a rupture with it. They oversaw the alleged discovery of underreported mineral exports by Acacia Mining. They constructed it as a moment of national revelation. Magufuli presented this as evidence of "unbelievable levels of looting and loss of government revenue". ${ }^{143} \mathrm{He}$ tied it to contemporary corruption; "everything we privatize, we enter into joint ventures, we partner with fraudsters." 144 This became a pretext for mining reforms, which he located in an "economic war". ${ }^{145}$ The opposition claimed it yielded nothing. ${ }^{146}$

CCM subsequently broadened this frontier of foreign enemies. Magufuli said that some donors "do not want good to our country". ${ }^{147}$ Moreover, while discussing electricity investors, he imagined the following anti-industrial extortion:

If national electricity is controlled by other people, you are finished... they may decide that today we raise bills or we cut the power... it means all industries you build will stop. ${ }^{148}$

Amid the mining dispute, the Finance Minister borrowed another phrase propagated on Twitter which alluded to Trump; he presented a "Tanzania First Budget". ${ }^{149}$ Altogether, CCM suggested that exploitation by companies frustrated industrial development. Asserting sovereignty over natural resources was incorporated into the restoration of Ujamaa. 
CCM invoked both industrial development and national struggle to justify autocratization. Tanzania became an electoral authoritarian regime after the transition to multipartyism in $1992 .{ }^{150} \mathrm{CCM}$ began reintroducing further authoritarian measures in 2014. ${ }^{151} \mathrm{CCM}$ construed criticism as divisive and opposed to peace. Thereby, it delegitimized criticism. ${ }^{152}$ For example, in anticipation of criticism by churches at 2018 Easter Sermons, Magufuli said "I call on religious leaders...to maintain peace...for the country's development." ${ }^{\prime 153} \mathrm{CCM}$ had routinely expressed messages through this logic of articulation in the recent past. ${ }^{154}$ However, in its revised discourse, CCM employed a similar logic to associate patriotism and development with criticism and treachery. CCM construed itself as in service to national development. Magufuli asked Tanzanians to "support the steps I am taking because it is for our national interest". ${ }^{155}$ Accordingly, criticism of CCM or its project harmed the nation, and so was unpatriotic. Magufuli said "Patriotism is being lost...I request the press to put Tanzania first... when Tanzania is damaged, you will also be damaged." ${ }^{156}$ CCM compounded the severity of these associations by locating Tanzania in the aforementioned struggle against foreign opponents and making the threat to Tanzania existential. Earlier in this speech, Magufuli said "someone said here that there are those who would like to see Tanzania destroyed". ${ }^{157}$ Therefore, criticism was not just unpatriotic, but seditious. Magufuli said that critics who disputed national statistics "want to derail us from our resolve to build the economy". ${ }^{158}$ This closely followed the logic of articulation by which liberation and developmental nationalisms delegitimized criticism.

By a similar logic of articulation, CCM elevated "development" above "politics". Magufuli said that "We should put Tanzania first and politics later. Tanzanians need 
development." 159 This enabled CCM to narrow the legitimate realm of opposition activity. Magufuli said that "They [the opposition] should let us implement CCM's election manifesto and judge us after five years". ${ }^{160}$ This depoliticized government and rendered opposition outside elections as unpatriotic and illegitimate. ${ }^{161}$ Similarly, CCM characterized opposition as treachery by connecting it to foreign enemies against whom the government was struggling to achieve development. After the revival of ACTL was frustrated by the seizure of a new aeroplane in Canada, a government spokesperson said that opposition politicians were "cooperating with foreigners to sabotage the implementation of several development projects." ${ }^{\text {"162 }}$ Indeed, opposition politicians were charged with sedition for encouraging the seizure. ${ }^{163}$ This complemented a longstanding aspect of CCM discourse whereby ethnic opposition was characterized as divisive and a prelude to civil strife. ${ }^{164}$ Thereby, the antagonisms and goals that CCM constructed through its restorationist developmental nationalism were used to justify authoritarianism and delegitimize opposition. ${ }^{165}$ Therefore, they gave developmental or liberation nationalist, rather than populist, justifications for authoritarianism, made in reference to transformation and foreign enemies, not "the elite" and liberal institutions which defy the "People's Will."" 166 Opposition and civic actors contested CCM's discourse. They characterized Magufuli as a paranoid tyrant. ${ }^{167}$ Worse, they suggested that his tyranny fomented division which forsook Nyerere's legacy of peace. ${ }^{168}$

\section{Conclusion}

Altogether, CCM resurrected a discourse which bore many similarities in discursive structure to liberation and developmental nationalisms. It constructed industrial development as a destination in the future towards which the nation was bound. It interpellated people as nation and generated an antagonism between it and foreigners who frustrated development. It invoked the imperative of development and the threat of 
foreigners to justify authoritarian measures, and vilified criticism and opposition as unpatriotic and seditious. Through this discourse it justified and continues to justify the constriction of political and civic space.

CCM did not contend that Tanzania has been continuously developing since independence. On the contrary, it embraced the claim that the nation has strayed from its developmental trajectory and promised to restore it. Thereby, it circumvented the rising rhetorical bar which liberation and developmental nationalisms must surmount. Restorationism makes developmental and liberation nationalisms versatile. Of course, this raises another question for future research: how will restorationist developmental nationalists in turn be judged if they do not realize the transformations they promise? Will one generation of restorationists replace another ad infinitum?

As I was making the final revisions to this article, Magufuli's initial response to COVID-19 was unfolding. He speculated that government health officials were on the "payroll of imperialists". ${ }^{169}$ By alleging both foreign conspiracy and domestic collaboration, he subsumed his interpretation of COVID-19 into his nationalist discourse. However, he also called COVID-19 a “devil". This emergent frame illustrates the creativity and variability of Magufuli rhetoric; ultimately, he crafts it, and he can break with it.

Restorationism represents a possible future of liberation and developmental ideologies in sub-Saharan Africa and beyond, a means for them to rejuvenate their discourses. In South Africa, counter-discourses had claimed that the ANC had betrayed its liberation mission by capitulating to big business or succumbing to elite corruption. President 
Democratization

Cyril Ramaphosa promised to partially turn back the clock in two ways; he would "turn the tide of corruption" and "reindustrialize". ${ }^{170}$ Thereby, South Africa would (re)embark upon a "new path" to become a "new country". ${ }^{171}$ Others not only construct such discourses but justify authoritarianism through them. Zimbabwe's ZANU-PF had articulated an emblematic liberation nationalism. ${ }^{172}$ Opposition voices had long-narrated it's deviation from liberation ideals. ${ }^{173}$ Emmerson Mnangagwa became president in a military coup entitled "Operation Restore Legacy". ${ }^{174}$ Coup-leaders claimed that some ZANU-PF leaders had betrayed liberation principles and justified the coup as a "restoration" of them. ${ }^{175}$ This restorationism enabled Mnangagwa to both be a "change candidate" and use aspects of his predecessors' liberation nationalism to justify authoritarianism. ${ }^{176}$

Beyond contemporary liberation nationalist regimes, almost all sub-Saharan African countries have historic developmental or liberation nationalist movements. Nostalgia for post-colonial moments could induce others to develop restorationist developmental nationalisms; by degrees, some already have. In Malawi, President Bingu wa Mutharika imagined a past era of "discipline" under one-party President Kamuzu Banda. ${ }^{\mathrm{ii}} \mathrm{He}$ constructed the subsequent loss of ="discipline" =and portrayed his own presidency as restorationist. He chastized officials and literally edified Banda in monuments. ${ }^{177}$ This accompanied authoritarian measures. Justifying Banda's actions, and implicitly, his own, he said "Sometimes discipline can be mistaken for dictatorship."178

\footnotetext{
ii I am entirely indebted to Calum Fisher for this example.
} 
Democratization

Looking forward, researchers should consider how others look back. As postcolonial moments grow distant, Africans have growing latitude to idealize the past without reaching into precolonial history. Political nostalgia for the postcolonial period merits further academic attention. Researchers should interpret how Africans re-remember history and draw on it to imagine possible futures. More broadly, in and beyond subSaharan Africa, studies of political discourse should privilege the destinations that discourses envisage. Thereby, they can explore the connections between authoritarianism and utopianism.

\section{Acknowledgements}

Thanks to Aikande Kwayu, Athuman Mtulya, Deogratias Munishi, Erick Mwakibete, Alastair Fraser and Calum Fisher for their insights, which improved the quality of this paper substantially. Thanks to Aikande Kwayu for their comments on previous versions of this paper. Special thanks to the research assistants, who wish to remain anonymous. All errors are my own. 


\section{Endnotes}

${ }^{1}$ Beresford, Berry and Mann, "Liberation Movements."

${ }^{2}$ Dorman, Understanding Zimbabwe.

${ }^{3}$ Beresford, Berry and Mann, "Liberation Movements;" Dorman, Understanding Zimbabwe.

${ }^{4}$ Beresford, "Regenerative Nationalism."

${ }^{5}$ Beresford, "Regenerative Nationalism," 884; Dorman, "Post-Liberation."

${ }^{6}$ Desai, "Introduction: Nationalisms."

${ }^{7}$ Paget, "Shrinking Space and Opposition Protest."

${ }^{8}$ Laclau and Mouffe, Hegemony and Socialist Strategy.

${ }^{9}$ Cheeseman, "A Divided Continent."

${ }^{10}$ Morse, How Autocrats Compete; Collord, "Comparing authoritarian parties and parliaments."

${ }^{11}$ Makulilo, "Unleveled Playfield."

${ }^{12}$ Paget, "Authoritarian Origins."

${ }^{13}$ Paget, "Shrinking Space."

${ }^{14}$ Laclau and Mouffe, Hegemony and Socialist Strategy.

15 Taylor, "Interpretation."

${ }^{16}$ Jacob and Pedersen, "New Resource Nationalism?"

${ }^{17}$ Schwartz-Shea and Yanow, Interpretive Research Design, 4.

${ }^{18}$ Pedersen and Jacob, Political Settlements, 10.

19 Taylor, "Interpretation."

${ }^{20}$ Schwartz-Shea and Yanow, Interpretive Research Design. Ibid., 189.

${ }^{21}$ Schwartz-Shea and Yanow, Interpretive Research Design, 84-89.

${ }^{22}$ Ibid., 95-97.

${ }^{23}$ Ibid., 106.

${ }^{24}$ Thanks to Aikande Kwayu for suggesting that I emphasize this point.

${ }^{25}$ Msekwa, "Reflections on CCM's history."

${ }^{26}$ Dorman, "Post-Liberation".

${ }^{27}$ Young, Ideology and Development in Africa, 23.

${ }^{28}$ Hendrickson and Zaki, "Modern African ideologies."

${ }^{29}$ Young, Ideology and Development in Africa, 27, 98.

${ }^{30}$ Beresford, "Regenerative Nationalism," 863.

${ }^{31}$ Tendi, "Robert Mugabe;" Dorman, Understanding Zimbabwe.

${ }^{32}$ Dorman, "Post-Liberation." 
33 "Mugabe;" Tendi, "Robert Mugabe;"

${ }^{34}$ Dorman, "Post-Liberation," 1096.

35 Tendi, "Robert Mugabe;" Dorman, "Post-Liberation".

${ }^{36}$ Dorman, "Post-Liberation," 1096.

${ }^{37}$ Bereford, Berry and Mann. "Liberation Movements."

${ }^{38}$ Ibid.

${ }^{39}$ Laclau and Mouffe, Hegemony and Socialist Strategy; Glynos and Howarth, Logics of Critical Explanation.

${ }^{40}$ Ibid., 145.

${ }^{41}$ Ibid.

${ }^{42}$ Ibid., 147 and 150.

${ }^{43}$ Ibid, de Cleen, "Populism and Nationalism."

${ }^{44}$ Beresford, "Regenerative Nationalism."

${ }^{45}$ Ferguson, The Anti-Politics Machine.

${ }^{46}$ Desai, "Introduction: Nationalisms."

${ }^{47}$ Nyerere, Uhuru na Ujamaa.

${ }^{48}$ Nyerere, Uhuru na Maendeleo.

${ }^{49}$ Ibid; Schneider, 'Freedom and Unfreedom."

${ }^{50}$ Schneider, 'Freedom and Unfreedom."

${ }^{51}$ Nkrumah, Class Struggle, 9, 47 and 80.

${ }^{52}$ Dorman, "Nationalism."

${ }^{53}$ Larmer and Lecocq, "Historicising Nationalism in Africa;" Glynos and Howarth, Logics of Critical Explanation.

${ }^{54}$ Dorman, "Narratives of nationalism."

${ }^{55}$ Dorman, "Nationalism."

${ }^{56}$ Ibid.; Dorman, "Post-Liberation Politics."

${ }^{57}$ Dorman, "Post-Liberation Politics", 1095.

${ }^{58}$ Beresford, "Regenerative Nationalism," 884.

${ }^{59}$ Ibid., 867.

${ }^{60}$ Beresford, Berry and Mann, "Liberation Movements," 1234.

${ }^{61}$ Dorman, 'Post-Liberation Politics', 1087.

62 de Cleen, "The Conservative Political Logic." 21.

${ }^{63}$ Ibid., 21.

${ }^{64}$ Payne, Fascism, 17. 
${ }^{65}$ Paget, "Mistaken for Populism."

${ }^{66} \mathrm{Ibid}$.

${ }^{67}$ de Cleen, "Populism and Nationalism."

${ }^{68}$ Canovan, "'People',"

${ }^{69}$ Urbinati, Me the People.

${ }^{70}$ Ibid.

${ }^{71}$ Dorman, "Nationalism."

${ }^{72}$ Hall and Young, Confronting Leviathan, 68. Thanks to Alastair Fraser for this example.

${ }^{73}$ Nkrumah, Consciencism, 70.

${ }^{74}$ De Cleen "The Conservative Political Logic."

75 Jacob and Pedersen, "New Resource Nationalism?;” Poncian, "Galvanising political support;" Nyamsenda, "Bulldozing like a Fascist?"

${ }^{76}$ Schwartz-Shea and Yanow, 4.

${ }^{77}$ Poncian, "Galvanising Political Support."

${ }^{78}$ Jacob and Pedersen, "New Resource Nationalism?"

${ }^{79}$ Ibid., 289.

${ }^{80}$ Ibid., 288.

${ }^{81}$ Pedersen and Thabit Jacob, 'Political Settlements," 10.

${ }^{82}$ Fouéré, "Julius Nyerere."

${ }^{83}$ Akew, "Sung and Unsung," Nyaluke and Connolly, "The Role of Political Ideas."

${ }^{84}$ Peace is associated with ethnic unity in this discourse.

${ }^{85}$ Phillips, "Pater Rules Best."

${ }^{86}$ Kwayu, "Politics of Image."

${ }^{87}$ Fouéré, "Julius Nyerere;" Kwayu, "Different Uses of Nyerere;” Becker, "Remembering Nyerere."

${ }^{88}$ Fouéré, "Julius Nyerere," 6.

${ }^{89}$ Ibid., 16.

${ }^{90}$ Ibid., 16.

${ }^{91}$ Kanyabwoya, 'Magufuli's Method in Madness."

${ }^{92}$ Jacob and Pedersen, "New Resource Nationalism?”; Poncian, "Galvanising Political Support."

${ }^{93}$ The East African, "Tanzanian President."

${ }^{94}$ Paget, "Mistaken for Populism;" Cheeseman, "Tanzania suffers."

${ }^{95}$ Becker, "Remembering Nyerere;" Kwayu, "Different uses." 
${ }^{96}$ Paget, "Mistaken for populism."

${ }^{97}$ Ngarabali, "CCM traitors."

${ }^{98}$ Masare, "CAG's report."

${ }^{99}$ BBC, "Tanzania's President Magufuli Sacks."

${ }^{100}$ Mwangonde and Mesomapya, "JPM Attacks Judiciary."

${ }^{101}$ Fouéré, "Julius Nyerere;" Becker, "Remembering Nyerere."

102 VoA, "Clottey interview."

${ }^{103}$ BBC, "Tanzanian Opposition;" Pedersen and Jacob, "Political Settlements," 22.

${ }^{104}$ For a more extensive discussion, see Nyamsenda 'Bulldozing Like a Fascist?', and Paget,

"Shrinking Space and Opposition Protest."

${ }^{105}$ Mugarula, "Nchemba."

${ }^{106}$ Jacobsen and Obulutsa, "Tanzania Loses Denmark Aid."

${ }^{107}$ Industrialization gained gradual prominence in CCM's vocabulary during Kikwete's second term. See for example Lugongo, "Kikwete Hits Out."

${ }^{108}$ Ministry of Finance and Planning, "National Five Year Development Plan."

${ }^{109}$ Magufuli, "Speech Officially Inaugurating."

110 *Original text: “...madarakani imejitahidi kurejea na kuweka katika vitendo dhana ya mwalimu nyerere ya uchumi wa viwanda." Nipashe, "Naibu waziri asema Magufuli afuata."

${ }^{111}$ Ministry of Finance and Planning, "National Five."

${ }^{112}$ Kolumbia, "We Erred."

${ }^{113}$ Emphasising industrialization was a direction deviation from the prognosis in the Arusha Declaration. This contradiction between the policies of Nyerere and Magufuli is not highlighted by the latter.

114 Thanks to Erick Mwakibete for stressing the importance of this initiative to me.

115 * Original text: “...baba wa taifa mwaka 1973 alisema tuhamie Dodoma ndio makao makuu ya nchi, Dodoma tunahamia na mimi ndio nakaribia kumalizia..." Millard Ayo, "Rais Magufuli."

116 *Original text: “...Magufuli anafuata nyayo za Nyerere...” Msungu, "Magufuli anavyotabiriwa."

${ }^{117}$ Boeing, "787 Dreamliner."

118 * Original text: "Tumefufua ATCL kurejesha heshima ya nchi...” Ayo, "Mambo 7 toka."

${ }^{119}$ The Citizen, "Hooray!"

${ }^{120}$ Thanks to Deogratias Munishi for emphasising the rhetorical importance of Stiegler's Gorge. 
${ }^{121}$ Dye, "Illiberal Modernizers."

${ }^{122}$ Msechu, "Magufuli atoa sababu tano."

123 *Original text: "kila alichokua amekitamani kukifanya Baba wa Taifa, Stigler's Gorge,

Kufanya nini, kujitegemea, tunaona matokeo yake tunapojaribu kuyafanya, tunafanikiwa..." State House Media, "Rais Dkt. John Magufuli."

124 * Original text: “Azimio la Arusha ukilisoma, unajua kila kitu kiko pale, kila kitu ambacho nchi yetu ilitakiwa ikijenge kipo mule." Ibid.

${ }^{125}$ Fouéré, "Julius Nyerere;" Kwayu, "Different uses of Nyerere;” Becker, "Remembering Nyerere."

${ }^{126}$ BBC, "Tanzanian Opposition;" O’Neill and Guinan, "Realising."

${ }^{127}$ I contacted @ClubMagufuli in April 2019 to enquire as to their true identity, but they wished to remain anonymous.

$128 @$ ClubMagufuli, “Tweet.”

${ }^{129}$ Kimboy, "JPM to MPs."

${ }^{130}$ Ibid.

131 *Original text unavailable. Azam TV, "Hotuba ya Rais Magufuli."

${ }^{132}$ Magufuli, "Speech Officially Inaugurating."

${ }^{133}$ Lugongo, "JPM Urges Tanzanians."

${ }^{134}$ Fouéré, "Julius Nyerere."

${ }^{135}$ O’Neill and Guinan, "Realising."

${ }^{136}$ Dye, "Illiberal Modernizers."

${ }^{137}$ Simba, "Tweet."

$138 @$ NiSisiSisiTZ, “Tweet."

139 * Original text: "Tanzania yenye maendeleo, Tanzania yenye sifa, Tanzania yenye neema inakuja, tumefanikiwa hili tutafanikiwa na mengine." Ayo, "Mambo 7."

${ }^{140}$ Makana, "When President Magufuli Ordered State Officials."

${ }^{141}$ The Citizen, "No Food."

${ }^{142}$ Jacob and Pedersen, "New Resource Nationalism?"

${ }^{143}$ The Guardian, "Revealed."

${ }^{144}$ Mohammed, "Tanzania President Urges."

${ }^{145}$ The Guardian, "Copper Concentrates Export Ban."

${ }^{146}$ BBC, "Tanzanian Opposition;"

${ }^{147}$ News24, "Donors Cut Aid."

148 *Original text unavailable. Azam TV, "Hotuba ya Rais Magufuli." 
${ }^{149}$ Kamndaya, "It's a 'Tanzania First' Budget."

${ }^{150}$ Makulilo, "Unleveled Playfield."

${ }^{151}$ Paget, "Shrinking Space and Opposition Protest."

${ }^{152}$ Pedersen and Jacob, "Political Settlements."

${ }^{153}$ Nwamkahe, "Magufuli Reaffirms Commitment."

${ }^{154}$ Phillips, "Pater Rules Best;" Schneider, "Freedom and Unfreedom."

${ }^{155}$ The Citizen, "Magufuli: We'll Negotiate."

156 Taylor, "'Be Careful, Watch It!"”

${ }^{157}$ Ibid.

${ }^{158}$ Lugongo, "JPM: Mind your Tongues."

${ }^{159}$ Kimboy, "JPM to MPs."

${ }^{160}$ The Guardian. "Magufuli Warns."

${ }^{161}$ Pedersen and Jacob, "Political Settlements."

162 Kamagi. "Govt admits."

${ }^{163}$ The Citizen. "Lissu Charged."

${ }^{164}$ Macdonald, "Age and Gender Voting," 51; Schneider, "Freedom and Unfreedom.”

${ }^{165}$ Paget, "Shrinking Space and Opposition Protest;" Pedersen and Jacob, "Political

Settlements."

${ }^{166}$ Urbinati, Me the People.

${ }^{167}$ BBC, "Tanzanian Opposition;" VoA, "Former Tanzania;" O’Neill and Guinan, "Realising."

${ }^{168}$ O’Neill and Guinan, "Realising."

169 Al Jazeera, "Tanzania president questions."

${ }^{170}$ Ramaphosa, "2018 State of the Nation."

${ }^{171}$ Ibid.

${ }^{172}$ Dorman, Understanding Zimbabwe.

${ }^{173}$ Ibid.

174 Tendi, "The Motivations and Dynamics," 51 and 54-55.

${ }^{175}$ Ibid., 54-55.

${ }^{176}$ Beardsworth, Cheeseman and Tinhu, "Zimbabwe," 5 and 17.

177 York, "The Cult."

${ }^{178}$ Smith, "Malawi President." 


\section{References}

Al Jazeera. 2020. "Tanzanian president questions coronavirus kits after animal test." May 03. https://www.aljazeera.com/news/2020/05/tanzania-president-questions-coronavirus-kitsanimal-test-200503174100809.html

Ayo, Millard. 2018. "Mambo 7 toka kwa Rais Magufuli akipokea ndege mpya Dreamliner." millardayo, July 8. http://millardayo.com/mhgnnh/

Ayo, Millard. 2018. "Rais Magufuli 'Namalizia December nahamia Dodoma, nayoyafanya Tanzania ni kumuenzi Nyerere." millardayo, October 14. http://millardayo.com/mhjy7y/ Azam TV. 2018. "Hotuba ya Rais Magufuli katika hafla ya utiaji saini mkataba wa Stiegler's Gorge." YouTube, December 13. https://www.youtube.com/watch?v=Epy9pK9H jA\&amp=\&feature=youtu.be

Babeiya, Edwin. "Multiparty Elections and Party Support in Tanzania." Journal of Asian and African Studies 47, no. 83 (2012): 83-100. doi.org/10.1177/0021909611418309

Becker, Felicitas. "Remembering Nyerere: Political Rhetoric and Dissent in Contemporary Tanzania.” African Affairs 112, no. 447 (2013): 238-61. doi:10.1093/afraf/adt019.

BBC. 2017. "Tanzania's President Magufuli Sacks 10,000 over Fake Certificates." April 28, https://www.bbc.co.uk/news/world-africa-39745362

BBC. 2019. “Tanzanian Opposition MP - Tundu Lissu.” January 21. https://www.bbc.co.uk/programmes/w3cswj9p

Beresford, Alexander. "The Politics of Regenerative Nationalism in South Africa." Journal of Southern African Studies 38, no. 4 (2012): 863-884. doi:10.1080/03057070.2012.744872.

Beresford, Alexander, Marie Berry, and Laura Mann. "Liberation Movements and Stalled Democratic Transitions: Reproducing Power in Rwanda and South Africa Through Productive Liminality.” Democratization 25, no. 7 (2018): 1231-1250. doi:10.1080/13510347.2018.1461209.

Boeing. 787 Dreamliner to Become Part of Air Tanzania fleet. Accessed December 72018. https://www.boeing.com/commercial/customers/air-tanzania/air-tanzania-787-order.page

Canovan, Margaret. “'People, Politicians and Populism.” Government and Opposition 19, no. 3 (1984): 312-327. doi: 10.1111/j.1477-7053.1984.tb01048.

Cheeseman, Nic. A Divided Continent: Regional Report Africa. Gütersloh: Bertelsmann Stiftung, 2018.

Cheeseman, Nic. 2018. "Tanzania Suffers Perils of Populism.” December 7. https://mg.co.za/article/2018-12-07-00-tanzania-suffers-peril-of-populism/ 
de Cleen, Benjamin. "The Conservative Political Logic: A Discourse-Theoretical Perspective." Journal of Political Ideologies 23, no. 1 (2018): 10-29. doi:10.1080/13569317.2017.1397917.

Collord, Michaela. "The Political Economy of Institutions in Africa: Comparing Authoritarian Parties and Parliaments in Tanzania and Uganda.” D.Phil thesis, University of Oxford, 2018.

Desai, Radhika. "Introduction: Nationalisms and their Understandings in Historical Perspective." Third World Quarterly 29, no. 3 (2008): 397-428. doi:10.1080/01436590801931413.

Dorman, Sara. "Narratives of Nationalism in Eritrea: Research and Revisionism." Nations and Nationalism 11, no. 2 (2005): 203-222. doi:10.1111/j.1354-5078.2005.00200.x.

Dorman, Sara. "Post-Liberation Politics in Africa: Examining the Political Legacy of Struggle." Third World Quarterly 27, no. 6 (2006): 1085-1101. doi:10.1080/01436590600842365.

Dorman, Sara. Understanding Zimbabwe: From Liberation to Authoritarianism. Oxford: Oxford University Press, 2016.

Dorman, Sara. "Nationalism in African Politics." In Oxford Research Encyclopedia of African Politics, edited by Nic Cheeseman. Oxford: Oxford University Press, 2019.

Dye, Barnaby. "Dam Building by the Illiberal Modernisers: Ideology and Changing Rationales in Rwanda and Tanzania." FutureDAMS no. 5. (2019)

http://hummedia.manchester.ac.uk/institutes/gdi/publications/workingpapers/futuredams/f uturedams-working-paper-005-dye.pdf

Ferguson, James. The Anti-Politics Machine: 'Development', Depoliticization and Bureaucratic Power in Lesotho. Cambridge: Cambridge University Press, 1990.

Fouéré, Marie-Aude. "Julius Nyerere, Ujamaa and Political Morality in Contemporary Tanzania.” African Studies Review 57, no. 1 (2014):1-24. doi:10.1017/asr.2014.3. Glynos, Jason and David Howarth, Logics of Critical Explanation in Social and Political Theory. London: Routledge, 2007.

Hall, Margaret, and Tom Young. Confronting Leviathan: Mozambique since Independence. London: Hurst, 1997.

Hendrickson, Joy and Hoda Zaki. “Modern African Ideologies.” In Oxford Handbook of Political Ideologies, edited by Michael Freeden. Oxford: Oxford University Press, 2013. Jacob, Thabit and Rasmus Pedersen. "New Resource Nationalism? Continuity and Change in Tanzania's Extractive Industries.” Extractive Industries and Society 5, no. 2 (2018): 287292. doi:10.1016/j.exis.2018.02.001.

Jacobsen, Stine and George Obulutsa. 2018. "Tanzania Loses Denmark Aid Over Rights Concerns after World Bank Scraps Loan.” Reuters, November 15. https://af.reuters.com/article/topNews/idAFKCN1NK1IR-OZATP 
Kamagi, Deogratius. 2017. "Govt Admits Plane Seized in Canada, Blames Opposition.” The Citizen, August 20. https://mobile.thecitizen.co.tz/news/Govt-admits-plane-seized-inCanada--blames-opposition/2304482-4064080-format-xhtml-62hohi/index.html

Kamndaya, Samuel. "It's a 'Tanzania First' Budget.” The Citizen, June 16.

https://www.thecitizen.co.tz/News/It-s-a--Tanzania-first--budget/1840340-4613366won1uc/index.html

Kanyabwoya, Damas. 2016. "Magufuli’s Method in Madness." The Citizen, June 1. https://www.thecitizen.co.tz/magazine/politicalreforms/Magufuli-s-method-in--madness/1843776-3227626-147t2wkz/index.html

Kimboy, Frank. 2017. "JPM to MPs: Let me Deliver on Mandate.” The Citizen, April 13. http://www.thecitizen.co.tz/News/JPM-to-MPs--Let-me-deliver-on-mandate/18403403888248-ncnmamz/index.html

Kolumbia, Louis. 2017. "We Erred in 1990s Sell-Offs.” The Citizen, July 6. http://www.thecitizen.co.tz/News/Magufuli--We-erred-in-1990s-sell-offs/18403404000720-r4iebd/index.html

Kwayu, Aikande. 2014. "Politics of Image or Can we Call it the Image Strategy? \#CCM vs \#opposition." May 19. http://www.aikandekwayu.com

Kwayu, Aikande. "Different Uses of Nyerere in the Constitutional Review Debates: A Touchstone for Legitimacy in Tanzania." In Remembering Julius Nyerere in Tanzania: History, Memory, Legacy, edited by Marie-Aude Fouéré. Dar es Salaam: Mkuki na Nyota, 2015.

Laclau, Ernesto and Chantal Mouffe. Hegemony and Socialist Strategy: Towards a Radical Democratic Politics. London: Verso, 2001.

Larmer, Miles and Baz Lecocq. "Historicising Nationalism in Africa." Nations and Nationalism 24, no. 4 (2018): 893-916. doi.org/10.1111/nana.12448

Lugongo, Bernard. 2011. "Kikwete Hits out at Foreign Managements." The Citizen, October 17. http://www.thecitizen.co.tz/news/-/16242-kikwete-hits-out-at-foreign-managements

Lugongo, Bernard. 2015. "JPM Urges Tanzanians to Embrace Unity, Hard Work.” The Citizen, December 26. https://www.thecitizen.co.tz/News/JPM-urges-Tanzanians-to-embraceunity--hard-work/1840340-3010064-format-xhtml-exyshlz/index.html

Lugongo, Bernard. 2017. “JPM: Mind your Tongues.” Daily News, October 24. http://www.dailynews.co.tz/index.php/home-news/53753-jpm-mind-your-tongues

Magufuli, J. P. Speech Officially Inaugurating the 11th Parliament of the United Republic of Tanzania in Dodoma. Dar es Salaam: United Nations Tanzania, 2015.

Makana, Fred. 2016. "When President Magufuli Ordered State Officials to Use Vitz." The Standard, August 15. https://www.standardmedia.co.ke/article/2000212100/whenpresident-magufuli-ordered-state-officials-to-use-vitz 
Makulilo, A. B. "Unleveled Playfield and Democracy in Tanzania." Journal of Politics and Law 5, no. 2 (2012): 96-106. doi:5539/jpl.v5n2p96.

Macdonald, Robert. "Age and Gender Voting Trends in the 2015 Tanzanian General Election." Journal of Eastern African Studies 12, no. 1 (2018): 44-62. doi.org/10.1080/17531055.2017.1410759.

Masare, Alawi. "CAG's report reveals flaws in public spending." The Citizen, April 7. https://www.thecitizen.co.tz/news/CAG-s-Report-reveals-flaws-in-publicspending/1840340-5517204-x7y7p4/index.html

Ministry of Finance and Planning. National Five Year Development Plan 2016/17-2020/21. Dar es Salaam: Government of the United Republic of Tanzania, 2016.

Mohammed, Omar. "Tanzania President Urges Increased Control of Mineral Wealth." Bloomberg, July 26. https://www.bloomberg.com/news/articles/2017-07-26/gold-tires-ofpolitical-shock-and-bore-with-swings-at-decade-low

Morse, Yonatan. 2019. How Autocrats Compete: Parties, Patrons and Unfair Elections in Africa. Oxford: Oxford University Press.

Msechu, Andrew. 2018. "Magufuli atoa sababu tano za kumuenzi Nyerere.” Mazagetini, September 6. http://magazetini3.rssing.com/chan-65451559/all_p2858.html

Msekwa, Pius. 2017. "Reflections on CCM's History of Rebranding Itself: The Story of 'CCM Kujivua Gamba' Re-Branding in 2011.” Daily News, February 2. http://www.dailynews.co.tz/index.php/columnist/66-pius-msekwa/48294-reflections-onccm-s-history-of-re-branding-itself-the-story-of-ccm-kujivua-gamba-re-branding-in-2011 Msungu, Renatha. 2016. "Magufuli anavyotabiriwa kuwa mfuasi halisi nyayo za Nyerere." Habari, October 14. https://www.ippmedia.com/sw/habari/magufuli-anavyotabiriwakuwa-mfuasi-halisi-nyayo-za-nyerere

Mugarula, Florence. 2017. “Nchemba: We've no Room for Gays.” Daily News, June 26. https://allafrica.com/stories/201706260179.html

Mwangonde, Henry and Janeth Mesomapya. 2016. "JPM Attacks Judiciary Over Anti-Graft War." The Citizen, February 5. http://www.thecitizen.co.tz/News/-/1840340/3063408//k9ecog/-/index.html

News24. 2018. "Donors Cut Aid to Tanzania After Rights Crackdown.” December 29. https://www.news24.com/Africa/News/donors-cut-aid-to-tanzania-after-rights-crackdown$\underline{20181229}$

Ngarabali, Julieth. 2016. "CCM Traitors will be Punished, Kikwete.” The Citizen, April 23. http://www.thecitizen.co.tz/News/-/1840340/3089436/-/kaqlgp/-/index.html

Nkrumah, Kwame. Class Struggle in Africa. London: Panaf, 1970. 
Nwamkahe, John. 2018. "Magufuli Reaffirms Commitment to Maintain Peace, Security.” The

Citizen, March 11. http://mobile.thecitizen.co.tz/news/Magufuli-reaffirms-commitment-tomaintain-peace--security/2304482-4336040-format-xhtml-k0q5rez/index.html

Nyaluke, David and Eileen Connolly. "The Role of Political Ideas in Multi-Party Elections in Tanzania: Refuting Essentialist Explanations of African Political Systems.” Irish Studies in International Affairs 24 (2013): 1-17. doi:10.3318/ISIA.2013.24.17.

Nyamsenda, Sabatho. "Bulldozing like a Fascist? Authoritarian Populism and Rural Activism in Tanzania." Paper presented at the Emancipatory Rural Politics Initiative Conference, The Hague, March 17-18, 2018.

Nyerere, Julius. Uhuru na Umoja: Freedom and Unity. Dar es Salaam: Oxford University Press, 1966.

Nyerere, Julius. Uhuru na Ujamaa. Freedom and Socialism. Oxford: Oxford University Press, 1968.

Nyerere, Julius. Uhuru na Maendeleo. Freedom and Development: A Selection from Writings and Speeches 1968-1973. Oxford: Oxford University Press, 1973.

O’Neill, Martin and Joe Guinan. 2018. "Realising Economic Justice in Tanzania - an Interview with Zitto Kabwe.” Renewal. http://www.renewal.org.uk/blog/realising-economic-justicein-tanzania-an-interview-with-zitto-kabwe-part-I

Paget, Dan. "Shrinking Space and Opposition Protest." Journal of Democracy 28, no. 3 (2017): 153-167. doi:10.1353/jod.2017.0053.

Paget, Dan. "Authoritarian Origins of Well-Organized Opposition Parties: The Rise of Chadema in Tanzania.” African Affairs 118, no. 473 (2019): 692-711. doi.org/10.1093/afraf/ady061.

Paget, Dan. "Mistaken for Populism: Magufuli, Ambiguity and Elitist Plebeianism in Tanzania." Journal of Political Ideologies (forthcoming, advanced access).

Payne, Stanley. Fascism: Comparison and Definition. Madison: University of Wisconsin Press, 1983.

Pedersen, Rasmus and Thabit Jacob. Political Settlement and the Politics of Legitimation in Countries Undergoing Democratisation: Insights from Tanzania. Manchester: University of Manchester, 2019.

Phillips, Kristin. "Pater Rules Best: Political Kinship and Party Politics in Tanzania's Presidential Elections." PoLAR 33, no. 1 (2010): 109-32. doi:10.1111/j.15552934.2010.01095.x.

Poncian, Japhace. "Galvanising Political Support through Resource Nationalism: A Case of Tanzania’s 2017 Extractive Sector Reforms.” Political Geography 69 (2019): 77-88. doi:10.1016/j.polgeo.2018.12.013.

Ramaphosa, Cyril. 2018 State of the Nation Address. Cape Town: South African Government, 2018. 
Schneider, Leander. "Freedom and Unfreedom in Rural Development: Julius Nyerere, Ujamaa Vijijini, and Villagization." Canadian Journal of African Studies 38, no. 2 (2004): 344-92. doi:10.1080/00083968.2004.10751289.

Schwartz-Shea, Peregrine and Dvora Yanow. Interpretive Research Design: Concepts and Processes. London: Routledge, 2012.

Simba, Mercy. 2018. "Tweet." Twitter, August 2. https://twitter.com/Mercy Simba

Smith, David. 2009. "The Cult of Hastings Banda Takes Hold.” The Globe and Mail, May 20. https://www.theglobeandmail.com/news/world/the-cult-of-hastings-banda-takeshold/article4273860/

State House Media. 2018. "Rais Dkt. John Magufuli amtembelea Mama Maria Nyerere nyumbani kwake msasani." YouTube. October 14. https://www.youtube.com/watch?v=jqZeOgY7tNk\&amp=\&feature=youtu.be

Taylor, Ben. 2017. “'Be Careful, Watch It!' - Translated Excepts from Speech of President Magufuli." Mtega, March 24. http://mtega.com/2017/03/be-careful-watch-it-translatedexcepts-from-speech-of-president-magufuli/

Taylor, Charles. "Interpretation and the Sciences of Man." In Readings the Philosophy of Social Science, edited by Michael Martin and Lee McIntyre. Cambridge, MA: Bradford Books, 1994.

Tendi, Blessings-Miles. "The Motivations and Dynamics of Zimbabwe's 2017 Military Coup.” African Affairs (forthcoming, advanced access). doi:10.1093/afraf/adz024.

Tendi, Blessings-Miles. "Robert Mugabe's 2013 Presidential Election Campaign.” African Affairs 39, no. 4 (2013): 963-970. doi:10.1080/01436590600842365

The Citizen. 2016. "No Food for Lazy People, JPM Warns." August 11. http://www.thecitizen.co.tz/News/1840340-3340302-k6jdvtz/index.html

The Citizen. 2017. "Magufuli: We'll Negotiate on our own Terms.” June 13. http://mobile.thecitizen.co.tz/news/Magufuli-reaffirms-commitment-to-maintain-peace-security/2304482-4336040-format-xhtml-k0q5rez/index.html

The Citizen. 2017. "Lissu Charged with Sedition at Kisutu Court." July 17. http://mobile.thecitizen.co.tz/news/Lissu-charged-with-sedition-at-Kisutu-Court/23044824030256-format-xhtml-vjlevh/index.html

The Citizen. 2018. “Hooray! Air Tanzania Boeing 787 Dreamliner Lands in D’Salaam.” July 7. http://www.thecitizen.co.tz/News/1840340-4652972-1m8bgyz/index.html

The East African. 2018. "Tanzanian President Magufuli Says His Party Will Rule 'Forever.”” July 17. https://www.theeastafrican.co.ke/news/ea/Tanzania-John-Magufuli-ccm-inpower-forever/4552908-4667434-oosawgz/index.html 
Democratization

The Guardian. 2017. “Copper Concentrates Export Ban... It's War, says Magufuli.” April 2.

https://www.ippmedia.com/en/news/copper-concentrates-export-ban-its-war-says$\underline{\text { magufuli }}$

The Guardian. 2017. "Revealed... Report to Expose Massive Looting of Mineral Wealth.” June 11. http://www.ippmedia.com/en/news/revealed-report-expose-massive-looting-mineralwealth

The Guardian. 2018. "Magufuli Warns of Tough Measures against Anti-Government

Protestors." March 18. https://www.ippmedia.com/en/news/magufuli\%20warns-toughmeasures-against-anti-government-protests

Urbinati, Nadia. Me the People: How Populism Transforms Democracy. Boston: Harvard University Press, 2019.

VoA. 2019. "Clottey Interview with Tundu Lissu, Tanzania Parliamentarian 1879341.” May 1. https://www.voanews.com/media/1879341

VoA. 2019. "Former Tanzania MP Says Magufuli Nyerere Era the Same.” October 11. https://www.voazimbabwe.com/a/former-tanzania-mp-magufuli-and-nyerereera/5118744.html

Young, Crawford. Ideology and Development in Africa. New Haven: Yale University Press, 1982.

York, Geoffrey. 2012. "The Cult of Hastings Banda Takes Hold." The Guardian, February 15. https://www.theguardian.com/world/2012/feb/15/malawi-leader-denies-new-mugabe @NiSisiSisiTZ. 2018. “Tweet.” Twitter, August 3. https://twitter.com/NiSisiSisiTZ 